\title{
The Immoral Moral Scientist. John Maynard Keynes.
}

Nina Paulovicova, University of Alberta

This paper undertakes to examine one aspect of the worldview of John Maynard Keynes - his alleged anti-Semitism. Keynes' anti-

24 Semitic utterances long attracted the attention of his biographers: some suspected anti-Semitism to be a permanent feature of Keynes, worldview, others refuted such claims and underlined the element of reproduction of anti-Semitic clichés that already permeated Keynes own milieu. The aim of this article is to reveal multiple layers that moulded the nature of Keynes' anti-Semitism within the context of his own socio-political milieu. When put in a dialogue with his political gestures, Keynes' problematic utterances become to be seen in a different light.

In view of the exhaustive analyses that John Maynard Keynes' many biographers have made of every aspect and nuance of his character, providing a short introductory portrait of him seems an almost vain task. And yet some of the descriptions of Keynes' personality are potentially striking. What does Virginia Woolf mean when she describes Keynes as being like a quicksilver on a sloping board - a little inhuman but very kindly, as inhuman people are? Similarly, Skidelsky`s description strikes the same chord when he calls Keynes an "immoralist" but also a magician, a dazzling performer, a saint

Past Imperfect

13 (2007) | @ | ISSN 1192-1315 
and a savior. ${ }^{1}$ Naturally, one is intrigued by these hints of an "inhuman" or "immoral" side of Keynes when confronted by Braithwaite's contradictory label of Keynes as "moral scientist" or somewhat traditional classificatory labels such as "scientific political economist" (Johnson and Johnson), a "great do-gooder" (James Mead) or "more than economist," which is Lydia Keynes' rather simple but poignant assessment of her husband. It is no doubt that one dimension of Keynes' immorality refers to his early sexual experience - homosexuality. Yet, it would be a mistake to evaluate the meaning of "immoral" merely from the perspective of late Victorian sexual moral codes. It is Keynes himself who provides us with clues about intellectual and behavioral dimension of his own immorality in his essay My Early Beliefs. Immorality connotes the idea of repudiation of customary morals, conventions and traditional wisdom. We [Keynes and his friends] recognized no moral obligation on us, no inner sanction, to conform or obey... ${ }^{2}$ Piero Mini claims that by being 'immoral' Keynes refers to extreme individualism that provides Keynes and his friends with right to judge their own actions. Being "immoral" thus means to be critical of generally accepted values and norms of their own milieu." ${ }^{33}$ It is exactly here, in the world of Keynes' character, where we have to start if we want to understand his stance in the world of politics and his attitude toward major philosophical, cultural and social phenomena of his time. The aim of this piece in particular is to examine a side of Keynes that was more or less ignored or

\footnotetext{
${ }^{1}$ Robert Skidelsky, "Keynes' political legacy”, in Omar Hamouda, John Smithin, "Keynes and Public Policy After Fifty Years," Vol. I: Economics and Policy (New York: New York University Press, 1988), 157.

${ }^{2}$ Piero V. Mini, John Maynard Keynes:A Study in the Psychology of Original Work (New York : St. Martin's Press, 1994), 28.

${ }^{3}$ Ibid., 29.
} 
deliberately pushed aside by historians - the nature and substance of Keynes' alleged anti-Semitism. It is not the aim of this piece to produce an elaborate list and individual contextual analysis of all of Keynes' problematic passages. What the author rather finds intriguing is how a twentieth-century audience ascribes a qualitatively different signifier to anti-Semitism than the audience of 26 Keynes' lifetime prior to the Nazi assault on the Jewish community in Germany. From the semiotic point of view it is the quality of two "semiospheres" that moulds the notion of anti-Semitism into qualitatively different signifiers and might lead to a misinterpretation of Keynes' moral values and political beliefs by a modern reader. Hence it is important to look at this kind of "inhuman" face of Keynes in the context of the nineteenth-century political and personal milieus. Nor does this piece aim to defend or in any way to diminish the weight of problematic anti-Semitic utterances. The evidence points to Keynes' uncritical appropriation and reproduction of anti-Semitic clichés rather than inner deeper resentment of the Jews. Therefore, closer examination of John Maynard Keynes' behavioral and psychological portrait would demonstrate the weaknesses of any attempt to label Keynes by existing concepts of anti-Semitism. In general, this piece insists on scholars' awareness to apply any kind of 'label' which itself provides the conclusive diagnosis: often no further investigation is needed. Yet, once such an investigation is carried out and the meaning of the problematic allconclusive term carefully deconstructed or the subjects' characteristics examined and extrapolated from the grip of label's stigmas, the plethora of unequal fragments behind the seemingly

\footnotetext{
${ }^{4}$ For more information about semiosphere see for example Yuri Lotman, Universe of the Mind: A Semiotic Theory of Culture (Bloomington: Indiana University Press, 1990). 
monolithic nature of both the, label and the subject becomes visible and perhaps even desperately confusing.

The idolization of heroes 'virtues and the demonization of villains' vices are temptations with which many biographers struggle in order to provide an objective analysis of their subjects. For various reasons, be they ideological, commercial or political, the prestige and respect of historical personalities is either embellished or diminished. In either case, we are offered a half-faced portrait, a suitable medium of opinion-manipulation that certainly lacks the desired element of objectivity. Being aware of this danger, I will strive to retain the balance of both - Keynes' virtues and vices.

Melvin Reder's article The Anti-Semitism of some Eminent Economists became an object of a disturbance that attracted the attention of some scholarship. Reder recorded the views of Hayek, Galbraith and Keynes to reflect on the mindset of this holy trinity of hominus economicus in the twentieth century. Rather than developing the connection between an individual's attitude toward anti-Semitism and the substance of his theories, Reder exposed a facet of contemporary culture of the trio and traced the differences lying behind them. It was Ronald Hamowy who on the basis of personal acquaintance with Hayek refuted Reder's claim about Hayek's anti-Semitism as unsubstantiated and challenged Reder to write a more insightful defense to support his argument. Here, addressing not only Hayek and Galbraith but also Keynes, Reder stressed the ambivalence of their anti-Semitism, a qualitative descriptor misread by Hamowy. In his defense, Reder operates with a notion of benevolence and hostility towards Jews. He puts these aspects in a dialogue with a socio-cultural environment of the individual economist, while strengthening his original claim about the ambivalence of the intellectuals anti-Semitism. The intensity of 
anti-Semitic expression was, in Reder`s view, displayed only within certain contexts and toward certain individuals. ${ }^{5}$ What were the endogenous and exogenous influences that could potentially become source of Keynes' alleged anti-Semitism? Is Reder's claim about the ambivalence of Keynes' anti-Semitism justified?

The intellectual atmosphere of the second half of the $19^{\text {th }}$ 28 century undoubtedly had a profound impact on the formation of Keynes as an intellectual. According to Allan Gruchy, J.M. Keynes' approach to economic studies, being totalistic or aggressive, stems from a new philosophical stream that rejected the Newtonian "atomic hypothesis," which identified the economic system as a static order composed of essentially independent parts. Keynes had abandoned Newtonian philosophy and adhered to a new anti-Newtonian view:

We are faced at every turn with the problems of Organic Unity, of Discreteness, of Discontinuity - the whole is not equal to the sum of its parts, comparisons of quality fail us, small changes produce large effects, the assumptions of a uniform and homogenous continuum are not satisfied. ${ }^{6}$

According to this line of argument the general idea of organic unity has a far-reaching impact in terms of rethinking the overall functioning of the state and economy. The state rather than being sum of its parts became ultimately viewed as an organic "whole" or "a body". The overall stance and respectability of the state on the world stage, as compared to other states, is negotiated through the criterion of "the ablest" and "the fittest" - notions that emerged from Darwinian evolution theory. In the context of an age when the glory

\footnotetext{
${ }^{5}$ Melvin Reder, "The Anti-Semitism of some prominent Economists," History of Political Economy, Vol. 32, No. 4 (Duke University Press, 2000), 834.

${ }^{6}$ John Maynard Keynes, Essays in Biography (London: Macmillan, 1933), 28.

Past Imperfect

13 (2007) | @ | ISSN 1192-1315
} 
and power of the state is measured by the largesse of a colonial dominium, the failures and weakness of the state are ascribed to a failure to attain the colonial dream. Victorians were prone to regard their age as an age of transition and profound crisis. Social tensions and growing distress gave way to expectations of either revolt or political revolution, or the possibility of social explosion. ${ }^{7}$ Hession's concerns about the imminent danger of social explosions are refuted, at least in connection with the early and mid-Victorian periods, by G.M. Young - undoubtedly one of the greatest historians of Victorian England. ${ }^{8}$ In his view it was Evangelicalism with its moral code of respectability, discipline, seriousness and hard work which helped the nation absorb the crisis that preceded economic or political change in the early Victorian period. Whereas Evangelicalism became a source of moral code and discipline, Utilitarianism supplied the philosophy that stressed reason, the idea of progress, and the necessity of reforms. ${ }^{9}$ In the middle of the nineteenth century the equilibrium of both streams resulted in the balance between tradition on the one hand and progress on the other. In the course of the nineteenth century, the number of those who believed that the government (or the state) should acquire a stronger position in order to defend and protect citizens and their private property had been increasing. The 1890 s bore serious signs of the decline of the Victorian age: whereas Germany was establishing its

${ }^{7}$ Charles H. Hession, John Maynard Keynes. A Personal Biography of the Man Who Revolutionized Capitalism and the Way We Live (New York: Macmillan Publishing Company, 1984), 7.

${ }^{8}$ In the center of G.M Young attention is a man. Ideas, opinions and impressions of contemporaries are center of Young's interest. Young believed that history can best learn from the opinion of an age. He immersed himself in the reading of primary sources. His effort was to decode the meaning of the words he read in primary sources documents: parliamentary debates, visual codes of contemporary art, newspapers, novels etc.

${ }^{9}$ James A. Colaiaco, "The Historian as an Insider: G.M. Young and Victorian England" in The History Teacher, Vol. 16, No. 4 (Aug, 1983), 531. 
"place on the sun," the dominance of Great Britain in world politics had been diminished. The shifts on the political chessboard ran in parallel with the collapse of traditional values and beliefs. Toward the end of the nineteenth century, Britain had been transformed from an oligarchy to a democracy - the complex process that was reflected in the crisis of Victorian traditional values that resulted from the 30 diminishing role of religion. Hence the fragmentation of midnineteenth-century Victorian "solid" culture was another accompanying side-effect of the overall societal crisis. Liberalism, in Young's view, needed an "injection of new doctrines." 10

These dazzling chiaroscuros of the profound political and societal changes helped mould the intellectual world of the young J.M. Keynes. An examination of Keynes' early writings helped to uncover his portrait as a philosopher. Backhouse and Bradley even celebrate Keynes as "the last great economist in the tradition of philosopher-economist." ${ }^{11}$ Yet there is no consensus over J.M. Keynes' philosophical background and the nature of his epistemology. Braithwaite, Giere and Gruchy underline empiricism as a basic philosophical strand behind J.M. Keynes' mode of reflection and knowledge. ${ }^{12}$ Gruchy sees Keynes' knowledge stemming from empiricism following in the footsteps of a postDarwinian orientation and ultimately reflecting the Weltanschauung

\footnotetext{
${ }^{10}$ Ibid., 535.

${ }^{11}$ Roger E. Backhouse and Bradley W. Bateman, "John Maynard Keynes: Artist, Philosopher, Economist," in Atlantic Economic Journal, Vol. 34, No. 2 (June, 2006), 149.

${ }^{12}$ Rod O'Donnell, "The Epistemology of J.M. Keynes," The British Journal for the Philosophy of Science, 41 (1990), 333. Rod O'Donnell refers to the following works: Richard Bevan Braithwaite, "Keynes as a Philosopher," in Essays on John Maynard Keynes, ed. Milo Keynes ( Cambridge: University Press, 1975); Ronald N. Giere, "Testing Theoretical Hypothesis," in Testing Scientific Theories, ed. John Earman ( Minneapolis: University of Minnesota Press, 1983); Allan Gruchy, "The Philosophical Basis of the New Keynesian Economics," Ethics, Vol. 58, No.4 (Jul.1984)
} 
of the twentieth century. ${ }^{13}$ On the other hand, Harrod and Hayek portray J.M. Keynes as a rationalist. ${ }^{14}$ Whereas Harrod and Hayek's characterization of Keynes as rationalist is rather that of an obiter dictum, O' Donell's basic thesis postulates that J.M. Keynes' rationalism was a "particular kind," a Cambridge rationalism. ${ }^{15}$ It is interesting to point to the contradiction between Keynes as empiricist or rationalist and the side of Keynes that indulged himself in the mysteries of irrational. Pierro Mini found a simple way out of this conundrum. He looks at the slow process of transformation of Keynes philosophical worldview. People simply change their philosophies in the course of their hectic lives. Keynes eventually repudiated rationalism and became fascinated by the realm of irrational forces in human nature: a transformation which might have been the outcome of the combination of multiple influences such as the World War I or Keynes' inner 'passionate anguish and soul searching." ${ }^{\text {16 }}$ Keynes' approach to the issues of contemporary ethics and morality seem to bear more weight in our effort to trace the nature of his anti-Semitism. Victorian Britain adhered to the utilitarianism of Bentham, against which Keynes revolted. The Benthamite moral code, "The greatest happiness of the greatest number," was attacked by Moore in his Principia Ethica, which had an immense influence upon Keynes. ${ }^{17}$ Skidelsky, Keynes' ablest biographer, explains how the Benthamite principle was translated

\footnotetext{
${ }^{13}$ Allan Gruchy, "The Philosophical Basis of the New Keynesian Economics," Ethics, Vol. 58, No. 4 (Jul.1984), 240.

${ }^{14}$ O'Donnell, 333. O'Donnell refers to the following works:

Roy F. Harrod, The Life of John Maynard Keynes ( 1951; reprint, New York: A. M. Kelley, 1969); Friedrich A. Hayek, New Studies in Philosophy, Politics, Economics and History of Ideas ( London: Routledge and Kegan Paul, 1978)

${ }^{15}$ O'Donnell, "The Epistemology of J.M. Keynes," 333.

${ }^{16}$ Mini, John Maynard Keynes, 30.

${ }^{17}$ George E. Moore, Principia Ethica ( Cambridge: Cambridge University Press, 1903)
} 
into an understanding of welfare economics: increased welfare led to increased happiness which ultimately resulted into increased goodness. This simple causal formula defined the role of an economist as an executor of goodness. Moore, on the other side, realized that not everything that people want and long for is necessarily good for them. Based on this view, wanting does not necessarily correlate with ethical goodness. Applying Moore's insight to the economic mode of thinking, one can conclude that reforms that produce higher levels of income do not increase the moral goodness of the universe. This was Moore's and Keynes' way of contemplating moral issues in the face of the earthly deeds and wants of homo economicus. ${ }^{18}$ Keynes' distaste for the acquisitive society and his humanitarian concern for the underdog seem to be partially related to this ethics. As moral goodness is not determined by higher levels of income, the effort should be channeled away from the cravings of society for more wealth. On the other hand, pessimism about reaching moral goodness can potentially lead to concerns about lower social strata as a vulnerable target of this mode of thinking. Keynes realized the bias of Moore's ethics. He struggled to take what was valuable in the Moorean teachings, namely "the idealism, the critical attitude and precise vocabulary, the honesty with self and the individualism." 19 On the other hand he was trying to escape its "narrowness, the self-centredness, the false view of human nature and of oneself, the lingering utilitarianism and the faint air of insincerity hanging over it." ${ }^{20}$ Keynes contemplated and frequently debated these issues within the Bloomsbury intellectual circle - "the Apostles."

\footnotetext{
${ }^{18}$ Omar Hamouda, John Smithin: "Keynes and Public Policy After Fifty Years," Economics and Policy (New York: New York University Press, 1988), 6.

${ }^{19}$ Mini, John Maynard Keynes, 31.

${ }^{20}$ Ibid., 31 . 
Within the Bloomsbury group, frequently labeled by its enemies as "an intellectual Mafia," 21 the talk was unusually frank. Be it art, sex, religion, the ordinary concerns of daily life, the members of the circle could express anything on their minds without any restraints. ${ }^{22}$ In fact, they used the mind as an agent provocateur to create a tension or even emotional crisis as an ideal condition for "knowledge of the inner." 23 Their discussions sometimes resembled of what Freud called "chimney sweeping," i.e. getting rid of the debris of their own psyches. ${ }^{24}$ Since 1905 young intellectuals would meet on Thursday evenings to debate the contemporary societal issues, criticize Victorian conventions or express their distaste of existing bureaucratic machinery. The artists and intellectuals within the circle either stubbornly defended their own stances or eagerly attacked the arguments and views of the others. Over time certain values had crystallized within the Bloomsbury group as a consequence of rather constructive debates: pacifism, feminism, friendship, creativity, freedom of expression and, above all, reason. ${ }^{25}$ The intellectuals did not work in isolation, but they debated the issues in public and actively engaged in political action directed at systematic reform at a ruling-class level, relating to lower classes as a matter of conscience. As Leonard Woolf, the husband of Virginia Woolf noted: "We were in the van of the builders of a new society which should be free, rational, civilized pursuing truth and beauty." 26 Yet, rationalism and reason did not always keep an upper hand

\footnotetext{
${ }^{21}$ Hession, John Maynard Keynes, 97.

${ }^{22}$ Ibid., 98.

${ }^{23}$ Mini, John Maynard Keynes, 215.

${ }^{24}$ Ibid., 215.

${ }^{25}$ Anna Upchurch, 'John Maynard Keynes, the Bloomsburry Group and the Origins of the Arts Council Movement," International Journal of Cultural Policy, Vol. 10, Issue 2, 2004, 203-217.

${ }^{26}$ Hession, John Maynard Keynes, 100.

Past Imperfect 13 (2007) | @ | ISSN 1192-1315
} 
within the group. An atmosphere of rebelling against rationalism and positivism and recovery of the unconscious and irrational permeated the group as well. Bloomsberries, being a vanguard of revolutionary ideas, displayed high tolerance for divergent views. They rejected Victorian values and respectability, justified homosexuality as a new counterculture, made femininity equal with masculinity, and exalted 34 the individual and friendship as the highest values. ${ }^{27}$ There is no doubt that the group was not free of either anti-Semitism or derogatory stereotyping. Scholarship does not provide a consensus about Bloomsbury anti-Semitism. Whereas Alexander described it as a "mild pervasive anti-Semitism as omnipresent and as unnoticed by Leonard's friends as the air they breathed"28, Reder refutes the claim that Bloomsbury anti-Semitism was unnoticed. This issue eventually requires more attention of scholarship. So far a brief sketch of societal changes that had formed young J.M. Keynes' world and the values of "the intellectual Mafia" which had, undoubtedly, molded Keynes' intellectual profile has been offered above. Before we proceed to the examination of Keynes' views of Jews let us briefly address the scholars' views about anti-Semitism.

Antisemitism is a socio-cultural phenomenon. One of the most challenging tasks is to define anti-Semitism on theoretical ground. A theoretical framework that would consistently embrace all the 'elements' pertaining to anti-Semitism would in fact amount to a theory representing modern society as a whole. ${ }^{29}$ In their effort to

\footnotetext{
${ }^{27}$ Anand Chandavarkar," Was Keynes Anti-Semitic?," Perspectives Economic and Political Weekly, May 6 2000, 1620 http://www.epw.org.in/showArticles, ( accessed December 2006)

${ }^{28}$ Peter F. Alexander, Leonard and Virginia Woolf: A Literary Partnerhsip ( New York : Harvester Wheatsheaf, 1992) 95.

${ }^{29}$ Martin Jay, "The Jews and the Frankfurt School: Critical Theory's Analysis of Anti-Semitism," New German Critique, No. 19, Special Issue 1: Germans and Jews. (Winter, 1980), 143. See also Theodor Adorno, The Authoritarian Personality (New York: Norton, 1982), 608.
} 
understand anti-Semitism in terms of fundamental dialectic of civilization, Adorno and Horkmeier concluded that "anti-Semitism is a deeply imprinted schema, a ritual of civilization.,30

Universality of anti-Semitism is frequently a focal dimension in scholarly debates. Vasecka defines anti-Semitism as "a universal, substitution phenomenon" by underlining its "depth, permanence and character." ${ }^{\prime 1}$ The idea of its universality is closely linked with the notion of continuity. Scholarly disputes yield "continuity - break" dichotomy, the debate briefly surveyed by Shulamit Volkov, the scholar who defined anti-Semitism as a "cultural code" embracing the "cluster of ideas values and norms." ${ }^{, 32}$ Continuity thesis embraced various notions. Ettinger's "eternal anti-Semitism," i.e. continuous transformation of the negative Jewish construct or Baron's "eternal hatred for eternal people" treated anti-Semitism as a permanent fixture of history. ${ }^{33}$ The emphasis on the culmination or acceleration of anti-Semitism in Talmon's study stood as a substitute model for the repetition of common patterns within continuity thesis. ${ }^{34}$ Some authors managed to find the way out of the "continuity - break" debate conundrum. Shulamit Volkov resolves this tension by introducing a thesis of ideal balance:

${ }^{30}$ Jay, "The Jews and the Frankfurt School," 145.

${ }^{31}$ Michal Vasecka, "Sociologicky vyzkum antisemitizmu na Slovensku po roku 1989 v kritickej perspective," Sociologia 38, (2006) No. 34, 285. Anti-Semitism defined as a "substitution phenomenon" - Jews bear responsibility for all sufferings of civilization, in fact Jews "substitute" or stand for these sufferings.

32 Shulamit Volkov, Germans, Jews, and Antisemites: Trials in Emancipation (Cambridge: Cambridge University Press, 2006), 67-71.

${ }^{33}$ Volkov, Germans, Jews, and Antisemites 69. Volkov refers to the following works: Shmuel Ettinger, Modern Antisemitism Studies and Essays (in Hebrew) (Tel Aviv: Moreshet, 1978); Salo Baron, "Changing Patterns of Antisemitism: A Survey," Jewish Social Studies, Vol. 38, No. 1 (1976), 5-38.

${ }^{34}$ Volkov, Germans, Jews, and Antisemites, 69-70. Volkov makes a reference to Jacob Talmon, The Unique and Universal. Some Historical Reflections ( London: Secker \& Warburg, 1965), $119-164$.

Past Imperfect 
In the last resort the two ["continuity" and "break" approaches] are always intertwined, only mixed in various degrees. Clearly from the historical point of view, every event is rooted in the past, but at the same time every phenomenon is at least in some way new and unique. The ongoing debate about break and continuity is thus only about correct proportions. ${ }^{35}$

36 Morphing through the course of the historical time, anti-Semitism acquires meanings projected by the specific geopolitical, economical, religious as well as ideological milieus. From latent form in the period of relative stability it might escalate into an all-pervasive racist equivalent at times of deep economic, political or national crisis (Berger). ${ }^{36}$ Hence, its depth can be measured on the scale from discrimination to outright violence (Katz) ${ }^{37}$ With regards to debate about Keynes, it is crucial to evaluate his alleged anti-Semitism against the cultural codes of his own milieu.

The essential body of literature looks at ethnic and racial identities as being constructed by cultural practices and cultural representations. David Norman Smith listed a number of these concepts: Langmuir's “chimeria," Gisela Bock's "social racism," Poliakov's "demonology," or Guillaumin's “racisation." ${ }^{38}$ Phillip

${ }^{35}$ Volkov, Germans, Jews, and Antisemites, 67.

${ }^{36}$ Vasecka, "Sociologicky vyzkum antisemitizmu na Slovensku," 285, referring to David Berger, History and Hate. The Dimensions of Antisemitism ( Philadelphia: The Jewish Publication Society, 1986)

${ }^{37}$ Vasecka, "Sociologicky vyzkum antisemitizmu na Slovensku," 286. referring to Jacob Katz: Jacob Katz, From Prejudice to Destruction. Anti-Semitism 1700 - 1933 (Cambridge MA: Harward University Press, 1994)

${ }^{38}$ David Norman Smith, “ The Social Construction of Enemies: Jews and the Representation of Evil” Sociological Theory_Vol. 14, No. 3. (Nov., 1996), 207. Smith refers to the following works: Gisela Bock, Antinatalism, Maternity and Paternity in National Socialist Racism," in Nazism and German Society, 1933 1945, ed. David F. Crew ( London: Routledge, 1994), 110 - 140; Colette Guillaumine, L'ideologie racist ( Paris and the Hague: Mouton, 1972); Gavin Langmuire, Toward a Definition of Antisemitism (Berkeley, Los Angeles and Oxford: University of California Press, 1990); Leon Poliakov, Harvest of Hate (London Elek, 1956). 
Dodd argues that specific forms of Englishness were being defined between $1880 \mathrm{~s}$ and $1920 \mathrm{~s}$ to incorporate "the other" which threatened to disturb the old social order. There is an effort to incorporate "the other" in order to preserve traditional values through an assimilation policy. The focus on newcomers' virtues such as sobriety, thrift and high moral values is part of the assimilation agenda. ${ }^{39}$ Brian Chayette argues that English writers actively constructed the myth of 'the Jew' in relation to their own literary and political concerns - hence the notion of "the protean instability of 'the Jew' as a signifier." 40

The scholarship on anti-Semitism in England displays a rich spectrum of views. On the one hand the older theories express the belief that anti-Semitism was somehow "different" in Britain than in the rest of Europe. William Brustein's comparative research on antiSemitism in the period between 1879 and 1939 in Great Britain, France, Germany, Italy and Romania was based on a rich data source that included legislation and major national newspapers. By refuting Goldhagen's notion of the exceptional nature of German antiSemitism, Brustein implicitly adheres to the view that anti-Semitism in the targeted countries is similar. Defined as "multifaceted prejudice," anti-Semitism became a viable tool to find the way out of the complex contemporary crisis. Yet Brustein also acknowledged specificities and different intensities of anti-Semitism within the targeted European milieus. With Italy exhibiting the lowest and Germany and Romania displaying the highest levels of prejudice

\footnotetext{
${ }^{39}$ Juliet Steyn, "The Complexities of Assimilation in the 1906 Whitechapel Art Gallery Exhibition 'Jewish Art and Antiquities," Oxford Art Journal, Vol. 13, No. 2. (1990), 44-50.

${ }^{40}$ Brian Cheyette, Constructions of 'The Jew' in English Literature and Society: Racial Representations, 1875-1945 ( Cambridge: Cambridge University Press, 1993), 8.
} 
against Jews, Britain is left somewhere "in between."41 The views about a lower intensity of anti-Semitism in Britain led to an interpretation of the course of Anglo-Jewish history as the one of optimism - the notion criticized and refuted by many historians. Gisela C. Lebzelter introduced the view that in England prior to WW I and WW II a "diffused" anti-Semitism lacked the vitality to be 38 mobilized into a viable political tool. ${ }^{42}$ But she treats the question of why English, as opposed to German, anti-Semitism was successfully diffused in cursory fashion. Todd M. Endelman sheds more light on the problem. He notes that the attention of the British Empire was directed to the more "exotic" peoples within their colonial domain. Affairs such as the India mutiny (1857), the Jamaica revolt (1865), and the Boer War (1899-1902) fed British anxieties about "racial fitness" and "racial degeneration" more than concerns about Jewish domination. ${ }^{43}$ Leon Poliakov offers a thorough treatment of the events in Great Britain that gave way to the rise of anti-Semitism in the period $1870-1933 .^{44}$ Serious deterioration of the climate was marked in 1901 by the coronation of Edward VII - "the pleasure loving son of Queen Victoria [who] preferred the company of actresses and Jews to that of aristocrats and prelates. ${ }^{45}$ The colony of over 100,000 Eastern European Jews, who settled in London accused of forming their own state within a state, as well as the rise of Jewish financiers and politician, released the trigger of antiSemitic sentiments. Yet, the Jews were not targeted as a single

\footnotetext{
${ }^{41}$ William I. Brustein, Roots of Hate: Antisemitism in Europe before the Holocaust (Cambridge: Cambridge University Press, 2003)

${ }^{42}$ Peter Pulzer, review of Political Anti-Semitism in England, 1918-1939, by Gisela C. Lebzelter, English Historical Review Vol. 95, No. 377 (October 1980): 939.

${ }^{43}$ Todd M. Edmann, Jewish Social Studies Vol. 11, No. 1 (2004): 52-92.

${ }^{44}$ Leon Poliakov, The History of Anti-Semitism, Vol. IV, Suicidal Europe, $1870-$ 1933 (Philadelphia: University of Pennsylvania Press, 1977), 187 -218.

${ }^{45}$ Ibid., 187.
} 
national-religious entity. The "Jewish question" was rather "the alien question." 46 Since London was the home of other foreign settlers, notably Germans, the natives often made a link between the Jewish and German settlers based on the shared German language. Needless to say, the Jewish newspapers opposed such a blurring of identities and criticized the Times for "describing all Jews as Germans."47 This perception proved to be fateful in the face of the tragic event of sinking of Lusitania in May 1915, which unleashed xenophobic sentiments and led to, what Poliakov calls the "refined anti-Semitism of the elite." ${ }^{48}$ While the First World War provided a stimulus for the rise of anti-Semitism, the October Revolution "furnished it with substantially more effective ammunition" and marked the phase of open anti-Semitism (1917 -1922)."49 The images of the revolutionary Jews undermining the traditional order and introducing the chaos were profoundly disseminated through media such as the Times, the Spectator or Evening Standard and haunted the minds of general public. The media not only flattered the superstitious prejudices of its audience but eventually built up the association between the phenomena causing disturbances as a consequence of "conspiracies" of the Jews. Yet, these tendencies were far from monolithic. Poliakov points to the persistence of the opposite tradition in the period between 1914 and 1918 which treated the Jews as the "heroes of an epic, the altars of a religion." ${ }^{50}$ Such attitude was widespread among those provincial Englishmen who grew up respecting the Old Testament. In regards to upper classes, Poliakov described antiSemitism as a "kind of political fashion... giving its supporters little

\footnotetext{
${ }^{46}$ Ibid., 189.

${ }^{47}$ Ibid., 191.

${ }^{48}$ Poliakov, The History of Anti-Semitism, 190.

${ }^{49}$ Ibid., 192, 218

${ }^{50}$ Ibid., 192.
} 
shivers of delight." ${ }^{, 51}$ After 1922, as it got used to the postwar world, the public view was no longer heated by the threat of world revolution and conspiracies of the Jews. The situation was changed in 1933, when Hitler and his disciple Mosley in England disturbed the relative peace once again. ${ }^{52}$

To assess the degree of pervasiveness of Keynes' antiSemitism, requires a great deal of attention to the question of "Who was generally defined as an anti-Semite in Keynes own societal milieu?" rather than "Which qualities of current forms of modern anti-Semitism can be traced in Keynes worldview?" By doing so, one diverts the attention from the "universality" or "continuity" thesis" of anti-Semitism and recognizes the specific cultural codes and modes of projecting the set of popular images within the targeted period and geographical space. Tracing and understanding of such cultural codes would shed more light on the contemporary definition of an anti-Semite. However, due to the complexity of the definitions of anti-Semitism, it is equally problematic to define an anti-Semite. Some scholars define an anti-Semite through the lens of agency embracing both, the object as well as the subject of anti-Semitism. ${ }^{53}$ The others define an anti-Semite against the scale of consistency of the prejudices and perseverance of activities or verbal attacks against the Jews and make a distinction between latent and active anti-

\footnotetext{
${ }^{51}$ Ibid., 214.

${ }^{52}$ Ibid., 217.

${ }^{53}$ For example in case of modern anti-Semitism its object is not defined and the term of "imaginary Jew" frequently pops up in scholarly debates. Wolfgang Benz (1993) claimed that "anti-Semitism is not only possible without Jews; it does in fact exists to [a] great [extent]." Bernd Marin expressed the phenomenon more bluntly "anti-Semitism without anti-Semites." (David Norman Smith, " The Social Construction of Enemies: Jews and the Representation of Evil" Sociological Theory, Vol. 14, No. 3. (Nov., 1996): 203-240.) 'Imaginary Jew' versus 'real anti-Semite' dichotomy was expressive of the cultural norm which needed to construct the negative "other" in order to identify the ideal 'self.'
} 
Semites. ${ }^{54}$ Leon Volovici defined latent anti-Semitism as uncritical appropriation and eventual reproduction of anti-Semitic prejudices and clichés - the definition which poignantly grasps the aspect of JMK's own uncritical utterances about Jews. The attempts to determine the stereotype of an anti-Semite within the larger context of authoritarian personality are also generally well-known. Theodore Adorno's famous F-scale released a torrent of criticism mainly due to the assumed correlation between degrees of racism and one's upbringing, i.e. authoritarian parenting style. ${ }^{55}$ Regardless the criticism, Adorno's F-scale was praised either as being a "good predictor of racist attitudes..." of inquiry." ${ }^{57}$ Despite the looming controversy, so called authoritarian syndrome traced within both, the intellectual and ideological as well as personal and behavioral realm was generally accepted. ${ }^{58}$ Apart from the famous F-scale, Adorno and his colleagues developed so called "A-S scale" with an aim to detect

\footnotetext{
${ }^{54}$ Michal Vasecka, "Sociologicky vyzkum antisemitizmu na Slovensku," 288. See also works of Leon Volovici, Nationalist Ideology \& Antisemitism. The Case of Romanian Intellectuals in the 1930s ( Oxford, New York, Soul and Tokyo: Pergamon Press, 1991), 190 - 194 and Richard Levy, Antisemitism in the Modern World. An Anthology of Texts ( Lexington, Massachusetts and Toronto: D.C. Heath and Company), 3-4.

${ }^{55}$ John J. Ray, "Why the F Scale Predicts Racism: A Critical Review," Political Psychology, Vol. 9, No. 4. (Dec., 1988): 672. Ray refers to number of Adorno's critics. See for example: Richard Christie and Marie Jahoda, Studies in the Scope and Method of the "Authoritarian Personality" (Glencoe Ill.: Free Press, 1954); Robert A. Altemeyer, Right-wing Authoritarianism (University of Winipeg: Manitoba Press, 1981); David W. McKinney, The Authoritarian Personality Studies. An Inquiry into the failure of social science research to produce demonstrable knowledge (The Hague: Mouton, 1973) etc.

${ }^{56}$ Ray, "Why the F Scale Predicts Racism: A Critical Review," 673.

${ }^{57}$ J.D. Meloen et al., "Authoritarianism and the Revival of Political Racism: Reassessments in the Netherlands of the Reliability and Validity of the Concept of Authoritarianism by Adorno," Political Psychology, Vol. 9, No. 3. (Sep., 1988): 413.

${ }^{58}$ Volkov, Germans, Jews, and Antisemites, 110.
}

Past Imperfect

13 (2007) | @ | ISSN 1192-1315 
latent anti-Semitic tendencies. ${ }^{59}$ Adorno concluded that "antiSemitism was subjective and irrational in nature, generally grounded in stereotypically distorted experience, rationalized in moralistic, super-egoistic terms, inclined to the 'mythological confusion' of mental dispositions and physical categories, and often linked to 'antidemocratic feeling. ${ }^{60}$ Can we utilize Adorno's scales in assessing inclinations of Keynes to authoritarianism and anti-Semitism? Clearly, the specificities of the historical period against which the scale was created cannot be ignored. Yet, the attempts to appropriate Adorno's scales and construct a parallel form of F-scale expressive of the cultural codes of the targeted milieus have been already made. For example, its empirical tools were used in the investigations into the support for a racist Dutch political party in 1980s. ${ }^{61}$ By slightly rephrasing the items of the scale, Netherlands' scholars validated Fscale and found a strong relationship with anti-Semitism. ${ }^{62}$ Similarly Pflaum constructed a parallel counterpart of the F-scale by collecting popular beliefs and myths in the $1920 \mathrm{~s} .{ }^{63}$ In order to assess the degree of pervasiveness of Keynes' anti-Semitism against his own historical period it would be an interesting project to construct a parallel scale of Adorno's scheme by collecting the popular perceptions of various historical timeframes: 1900 - 1914, First World War England, interwar England and finally the period of

\footnotetext{
${ }^{59}$ Martin Jay, "The Jews and the Frankfurt School: Critical Theory's Analysis of Anti-Semitism," New German Critique, No. 19, Special Issue 1: Germans and Jews. (Winter, 1980): 142.

${ }^{60}$ Ibid., 142. See also Adorno, 605.

${ }^{61}$ D. Meloen, L. Hagendoorn, Q. Raaijmakers, L. Visser, “Authoritarianism and the Revival of Political Racism: Reassessments in the Netherlands of the Reliability and Validity of the concept of Authoritarianism" by Adorno et al. Political Psychology, Vol. 9, No. 3. (Sep., 1988), 413-429.

62 Ibid., 417.

${ }^{63}$ Ray, "Why the F Scale Predicts Racism: A Critical Review," 674. Ray refers to J. Pflaum, "Developoment and Evaluation of Equivalent Forms of the F-scale," Psychological Reports. Vol. 15 (1964): 663-669.
} 
Hitler's succession to power 1933 - 1945 in Europe. Eventually, to analyze Keynes' personal and moral dispositions against the items of such an appropriated scale would be another challenging task.

When he was seventeen years old, J.M. Keynes wrote a provocative essay, "The Differences between East and West: Will They Ever Disappear?" Through the examples of the Chinese and the Jews, the young Keynes tried to discover whether the European and Oriental branches of human race would continue to live side by side or whether eventually one would succeed in absorbing the other. Jews were, in his teen view, the accursed race..."they have in them deep-rooted instincts that are antagonistic and therefore repulsive to the European, and their presence among us is a living example of the insurmountable difficulties that exist in merging race characteristics, in making cats love dogs" ${ }^{64}$ Chandavarkar acknowledged that as an adult Keynes never outgrew his teen perception of the Jew. J.M. Keynes held even more radical views about the Chinese. He condemned the attempt to transform the Chinese into "a race of tigers" as a futile effort; he added that Europeans could hope nothing less than a second flood that would exterminate them. ${ }^{65}$

The following is an example of one of Keynes` frequently cited utterances about which historians are particularly uneasy as they indicate anti-Semitism as a part of Keynes' worldview. Upon meeting Einstein, Keynes reflected his impression as follows:

He is a naughty Jew boy covered with ink -that kind of Jew - the kind which has its head above water, the sweet, tender imps who have not sublimated immortality into compound interest. He was the nicest, and the only talented person I saw in all Berlin, except perhaps old

${ }^{64}$ Chandavarkar, "Was Keynes Anti-Semitic?," 1619.

${ }^{65}$ Ibid. 
Fuerstenberg, the banker Lydia liked so much, and Kurt Singer, two foot by five, the mystical economist from Hamburg. And he was a Jew; and so was Fuerstenberg and so was Singer. And my dear Melchior is Jew too. Yet if I lived there, I felt I might turn anti-Semite. For the poor Prussian is too slow and heavy on his legs for the other kind of Jews, the ones who are not imps but serving devils, with small horns, pitch forks, and oily tails. It is not agreeable to see civilization so under the ugly thumbs of its impure Jews who have all the money and the power and brains. I vote rather for the plump hausfraus and think fingered Wandering Birds. But I am not sure that I wouldn't even rather be mixed up with Lloyd George than with the German political Jews. ${ }^{66}$

Three layers stand out from this particular Keynes' utterance: a) Keynes' anti-Semitism is articulated through his distaste for the acquisitive elements of society, which he ascribes to Jews as a part of their national stereotype; b) the notion of "impure thumbs" of the "impure Jews" reflects the racial theories of Keynes' era that permeated him and his contemporaries in different modes of different intensity; c) finally, his comparison of the Jews to "serving devils" reflects Keynes' fascination with irrational, dark forces in society. Hints of dark forces, religion, and magic seem to be a favorite descriptive element of Keynes in describing an individual in the context of national stereotyping of the Jews. When Keynes recognized Melchior`s ${ }^{67}$ hatred of Russia, he acknowledged that the Jewish banker was obsessed with the "dark forces." Upon this revelation Keynes understood that Melchior was - "a strict and

\footnotetext{
${ }^{66}$ Hession, John Maynard Keynes, 225-226.

${ }^{67}$ More on Melchior and Keynes' relationship see in: Elisabeth Johnson and Harry Johnson, The Shadow of Keynes (Oxford: Basil Blackwell, 1978), 45 - 61.

Past Imperfect

13 (2007) | @ | ISSN 1192-1315
} 
upright moralist, a worshiper of the Tablets of the Law, a Rabbi." 68 Keynes was aware of the categories of modern psychology. His life time experience demonstrated that reality was not the realm of reason but rather the world of unpredictable dark and mysterious forces. ${ }^{69}$ Keynes was caught by the power of magic, which he seemed to seek behind any form of the extraordinariness. ${ }^{70}$

Let us now turn to Keynes' concern with the acquisitive elements of society. Keynes' concern with the acquisitiveness of society, so similar to Marx's, is tellingly expressed in his General Theory: "It was not natural for a population, of whom so few enjoyed the comforts of life, to accumulate so hugely." ${ }^{71}$ It is interesting to follow Keynes' argument about love of money as a possession as opposed to money as a means to the enjoyments and realities of life. While the latter in Keynes eyes is a justified love, the former is a form of "disgusting morbidity", "a semicriminal and semipathological propensity which one hands over with a shudder to the specialists in mental disease." 72 The following comment was made by Keynes about the French Minister Klotz: "a short, plump, heavy-mustached Jew..." who “...with a gesture of his hands indicated to everyone the image of hideous Jew clutching a money bag..." 73 Jews, in Keynes eyes, are stereotypically associated with a morbid side of money-love. Minister Klotz, according to Keynes, was a target of general animosity and was hated because of his

\footnotetext{
${ }^{68}$ Hession, John Maynard Keynes, 142. Propensity of Keynes to compare some of the respectable figures "rabbi" also stands out from his biographies. Melchior and Leonard Woolf were addressed "rabbi" by Keynes.

${ }^{69}$ Hession, John Maynard Keynes, 171. Not only this observation fit with Keynes worldview (Moore) but also emerges in his General Theory.

${ }^{70}$ See for example, Robert Skidelsky: Keyne`s political legacy, in: Omar Hamouda, John Smithin: "Keynes and Public Policy After Fifty Years," Economics and Policy (New York: New York University Press, 1988), 159.

${ }^{71}$ Hession, John Maynard Keynes, 151.

${ }^{72}$ Ibid., 243.

${ }^{73}$ Ibid., 142.
} 
stubborn effort to control German "goold" (French pronunciation of the word gold -NP) which he obstinately tried to save for the payment of reparations. Regarding this fact, the derogatory "image of hideous Jew" emerged in Keynes' description as a reaction to Klotz's general unpopularity and his unwillingness to come to a mutual satisfactory agreement about the control of German gold. 46 Keynes' propensity to slip into anti-Semitism and general stereotyping seems to be rather selective. The decisive element in his overall judgment of the targeted personality is the ability of the individual to attract Keynes' attention through the qualities that stand out from the mediocre. It is the quality and uniqueness of one's personality, rather than one's national stereotype that preoccupies Keynes. Although, it must be admitted that Keynes' amusement in the shocking and surprising twists in assessment of one's character could easily refute this claim. We might conclude that an overall impression plays a role in his propensity to make negative comments about an individual's nationality. It is interesting that even in the case of Klotz, who was a target of general animosity and hatred at the Paris Conference, Keynes' expression of a sympathy for this “ poor man" is reflective of Keynes' other concern for the underdog. To support the argument about the selectiveness of Keynes' antiSemitism, let us turn to Melchior, the Jew who represented the defeated German government at the Paris conference. Keynes' depiction of Melchior obviously demonstrates his propensity to protect the weak, downtrodden, or, as in Melchior's case, the defeated individual. Melchior, "the honest animal at bay", "the honorable animal in pain", "this Jew, for such, though not by appearance ...upheld dignity of defeat", ${ }^{74}$ elicited a genuine

\footnotetext{
${ }^{74}$ Hession, John Maynard Keynes, 139.

Past Imperfect 
sympathy of Keynes. Melchior`s qualities were so powerful that his portrayal has been seen as the classic description of "the good German." Keynes feelings for Melchior were articulated by historians either as a flirtation, platonic in nature, or as love, which may have influenced him in espousing the German cause then and later. $^{75}$ That the Jewish agency of Melchior is marginal in Keynes' overall impression of this statesman supports the conclusion that Keynes 'anti-Semitism was a matter of contemporary fancy in stereotyping rather than a sign of political anti-Semitism or xenophobia. This conclusion stands in line with that of Reder, who also did not trace any initiation of political or economic proposals of an anti-Semitic nature to Keynes as opposed to, for example, Hayek. $^{76}$

Keynes' penchant for the pejorative stereotype applied not only to Jews but to other nationalities and social classes as well. ${ }^{77}$ His deeply rooted Anglo-centrism spontaneously produced antiAmericanism. ${ }^{78}$ His well-known reservations about the new motor vehicles might well have been associated with his reservation about Americans. ${ }^{79}$ Writing to Duncan Grant, he said, "The only really sympathetic and original thing in America is the niggers, who are charming". ${ }^{80}$ His frequent criticism of France seems to be a result of the political and diplomatic tension of the Paris Peace Conference. The revenge of France on Defeated Germany was a thorn in the eye of Keynes. "France demands her bond and her forfeit too - to cut out

\footnotetext{
${ }^{75}$ Ibid., 141.

${ }^{76}$ Hession, John Maynard Keynes, 268.

${ }^{77}$ Reder, "The Anti-Semitism of some prominent Economists," 839.

78 David Laidler, "Skidelsky's Keynes: A Review Essay," European Journal of the History of Economic Thought, Vol. 9, No. 1 ( March, 2002): 100.

${ }^{79}$ Hession, John Maynard Keynes, 57.

${ }^{80}$ Robert Skidelsky, John Maynard Keynes. The Economist as Savior 1920 -1937 (London: Macmillan, 1992) 342.
} 
Germany's heart and to extract the utmost ducat at the same time; greed and fear and revenge, overreaching one another, until they end in a sort of nihilism... "81 At the Inter-Allied Council for War Purchase and finance, he complained at having to listen to "...vain mendacious and interminable French hateful Yank twang" 82 Russians were not spared Keynes' merciless comments either. In 48 Essays in Persuasions, one finds the following derogatory comments: "...beastliness in the Russian nature..." or "...cruelty and stupidity of old Russia...” out of which “...nothing could ever emerge, but that beneath the cruelty and stupidity of New Russia some speck of the ideal may lie hid...." "Beastliness" was also ascribed to "avaricious" Jews. ${ }^{83}$ Keynes opinion about women expressed in his earlier life when he encountered a series of homosexual relationships is another example of his merciless spontaneity, his ability to strike an unaware listener on the spot like a thunderbolt: "I seem to hate every movement of their [women's] minds. The minds of men, even when they are ugly and stupid, never appear to me so repellent." However vilifying nature of this remark, it is in stark contrast with strong protests against discrimination against the women in his mature life. ${ }^{84}$ Apparently, women would fit in Keynes category of downtrodden underdogs as they seem to reflect his compassion for the weak. Another contradiction emerges from his view of politicians. On the one hand, Keynes viewed them as charlatans who manipulated the public with their propaganda; on

\footnotetext{
${ }^{81}$ Ibid., 126.

${ }^{82}$ Ibid., 343.

${ }^{83}$ John Maynard Keynes, Essays in Persuasion (New York: W.W. Norton \& Company. Inc., 1963), 310 - 311.

${ }^{84}$ Hession, John Maynard Keynes, 74.

Past Imperfect

13 (2007) | @ | ISSN 1192-1315
} 
the other hand, he could readily turn into an enthusiastic supporter of any leader pursuing a policy of which he approved. ${ }^{85}$

When we put Keynes' derogatory remarks in a dialogue with his political acts concerning the targeted individuals, a stark contrast between them emerges. Rather than analyzing Keynes' policy toward the targeted groups, let us follow the main thesis of this analysis and focus on his political acts that might possibly compensate for the burden of his disturbing anti-Semitic remarks, whose nature I have already partially addressed. Keynes 'support of Zionism remains a theme so far largely unnoticed by historians ${ }^{86}$ Annand Chandavarkar was probably the first historian to call attention to this topic. It is hardly known that Keynes was the only non-Jewish member of a high-powered advisory committee responsible for preparing a report on Zionist efforts to establish a national home in Palestine, which was to be presented in Paris at the Peace Conference in February $1919 .^{87}$ Keynes` name, however, is not recorded in the standard histories of Jews and Zionism, despite his active involvement in the committee. Whether this might have been a consequence of Keynes` spontaneous outbursts of anti-Jewish remarks remains a question to be answered. Nonetheless, this effort was again completely congruent with Keynes' compassion for underdogs. On the side, Keynes pro-Zionist activity must have posed an acute dilemma as Edwin Montagu, one of Keynes` dearest benefactors, was the fiercest opponent of Zionism. In the course of events, Keynes' views turned to be more reserved as he became aware of the political costs of Zionism. Later during the persecution of Jews in Germany in 1930s, Keynes decisively stood on the side of the Jews. The letter written to

${ }^{85}$ Elisabeth Johnson and Harry Johnson: The Shadow of Keynes (Oxford: Basil Blackwell, 1978), 18.

${ }^{86}$ Chandavarkar, "Was Keynes Anti-Semitic?," 1622.

${ }^{87}$ Chandavarkar," Was Keynes Anti-Semitic?," 1622. 
Professor Spiethoff, who was arranging the publication of a German translation of "National Sufficiency," supports this claim:

Forgive me for my word about barbarism. But the word rightly indicates the effect of recent events in Germany on all of us here... It is many generations in our judgment since such disgraceful events have occurred in any country pretending to call itself civilized...If you tell me that these events have taken place, not by force but as an expression of the general will ...that in our view would make some of the persecutions and outrages of which we hear...ten times more horrible. ${ }^{88}$

Keynes even suggested making an offer to Germany to make organized arrangements for all German and Austrian Jews who wished to emigrate and be naturalized elsewhere. ${ }^{89}$ He readily intervened in favor of interned Jewish economists. According to editors of The Collected Writings, Keynes was one of the most active in succoring the Jewish refugees.

There is a certain validity in Reder's claim that the antiSemitism of educated people is a product of their more delicate sensibilities. ${ }^{90}$ Keynes` formative years as an intellectual at Eton and Cambridge, the impact of the Bloomsbury intellectual circle, and finally, his participation on the stage of high politics constituted the extrinsic stream which readily projected the societal prejudice and specific images of the Jew upon Keynes. Keynes himself in his Two Memoirs acknowledged "rationalism and cynicism" as a two qualities of the Cambridge intellectual milieu. ${ }^{91}$ Furthermore, Keynes

\footnotetext{
${ }^{88}$ Robert Skidelsky, John Maynard Keynes. The Economist as Savior 1920 -1937 (London: Macmillan, 1992), 486.

${ }^{89}$ Chandavarkar, "Was Keynes Anti-Semitic?," 1622.

${ }^{90}$ Reder, "The Anti-Semitism of some prominent Economists," 849.

${ }^{91}$ John Maynard Keynes, Two Memoirs. Dr. Melchior: A defeated enemy and My Early Beliefs (London: Rupert Hart - Davis, 1949), 79. 
was undoubtedly a ferocious reader. It is not surprising that voluminous readings could have presented theories that either hinted at, or were expressive of, anti-Semitic or racist ideology. For example, it is known that Keynes did much reading of "superb Hume" who, besides his great philosophical contribution, compared the intelligence of "the Negro" to that of a parrot. Scientific racism was well rooted in the great works of the intellectual elite. ${ }^{92}$ Living a life in high gear and being constantly overworked and buried by projects are the factors that rarely allowed Keynes to pull the breaks. The same hectic process was typical of his way of thinking and of judging others. Rarely there was a time for a deeper contemplation before the final, often striking judgment. Keynes` judgments were spontaneous, not necessarily rational and not at all tactful. It seems as if in Keynes' world the moment of the birth of the thought was the unique and perfect moment for its articulation regardless of what impact or damage it could eventually produce. Johnson \& Johnson recognize that Keynes' reactions to events were immediate. Similarly, Chandavarkar noted Keynes' art of “brisk epigrammatic evaluations of men and matters." ${ }^{, 93}$ Keynes himself held the view that "words ought to be a little wild - for they are the assault of thoughts upon unthinking. "'44 Some scholars ascribe the 'brittleness' of his conversations to neurotic condition as a result of his emotionally charged life and involvement in the world of high politics and frenzied economic markets. Piero Mini describes individuals suffering from neurotic condition as emotionally susceptible, 'cranky', earnest and quick to recognize an injustice. He calls Keynes an "existentialist man" whose extreme sensitivity in

\footnotetext{
${ }^{92}$ See for example Robert Proctor, Racial Hygiene. Medicine under the Nazis (Cambridge, London: Harvard University Press, 1988), 10 - 45.

93 Chandavarkar," Was Keynes Anti-Semitic?," 1623.

94 Johnson and Johnson, The Shadow of Keynes, 20. 
combination with "superior cold intelligence" made him into a "nervous wreck." $" 95$ Clearly, the dualism of emotional susceptibility and intelligence made Keynes a master of words, who was perfectly aware of their subtlest meanings and overtones. Almost like a professional photographer, he could freeze a figure in a single snapshot with a hint of humor, satire, fantasy, mockery or mystery. ${ }^{96}$

As we can see, Keynes expressed respect for people who managed to succeed regardless of their national or social background. But it was not so much success as the ability to command respect that overcame Keynes' prejudices and propensity to stereotype. Keynes never referred, at least publicly, to Abrahams (financial secretary and later under secretary of state for India) and Montagu (the secretary of state for India also played a decisive role in advancing the public career of Keynes) as Jewish. Both of them were his mentors. Reading, who contributed to the clarification and development of Keynes ideas on the complexities of Indian finance, and Edwin Montagu was another Jewish friend whom Keynes "immensely liked." What conclusion can we draw from the above mentioned analysis in the face of existing debates?

\section{Conclusion}

Reder rejects Skidelsky`s theory that Keynes' anti-Semitism was "little more than a theological fancy, the expression, perhaps of some unresolved conflict about his own nonconformist roots". ${ }^{98}$ In Reder's view Keynes' anti-Semitism was definitely more than just a theological fancy as Keynes characterized Jews to be Nazis or

${ }^{95}$ Mini, John Maynard Keynes, 13.

${ }^{96}$ Ibid., 35.

${ }^{97}$ Chandavarkar," Was Keynes Anti-Semitic?," 1620.

${ }^{98}$ Skidelsky, John Maynard Keynes, 239.

Past Imperfect 
Communists at heart. ${ }^{99}$ He concludes that Keynes was well aware of his own anti-Semitism and felt no urgency to reconcile it with his feelings for his Jewish friends. In his view, stereotyping does not necessarily express disesteem of the Jewish individual and did not prevent relationships between Christians and Jews. We can support this claim by the example of such a relationship in the Bloomsbury group. Virginia Woolf married to Leonard Woolf, who was Jewish, often made anti-Semitic remarks in the presence of her husband and other Jewish members. Reder interprets this reconciliation of pervasive anti-Semitism and close Christian-Jew relationship as a manifestation of a class-oriented attitude toward personal relationships in general. ${ }^{100}$ All in all, Reder's interpretation seems to be somewhat more critical than Chandavarkar's perception of Keynes' anti-Semitism as "a peripheral fringe of an inherently compassionate personality ${ }^{101}$ or Berlin`s interpretation of "club antiSemitism" which "is not a deep, acute hostility to Jews." 102 We can dismiss the religious undertone of Keynes' anti-Semitism as Keynes interest in religion was merely intellectual and Keynes himself "passed painlessly into a natural state of agnosticism."103

According to Barry A. Kosmin, one of the fallacies of our time is the view that educated people are inherently less prejudiced than the uneducated: "Conventional wisdom holds that prejudice equals ignorance and therefore can be fought - and ultimately eradicated- through education. More education begets more

\footnotetext{
${ }^{99}$ Reder, "The Anti-Semitism of some prominent Economists," 838.

${ }^{100}$ Reder, "The Anti-Semitism of some prominent Economists," 840.

${ }^{101}$ Melvin Reder, "Reply to Hamowy`s Note on Hayek and Anti-Semitism," History of Political Economy, Vol. 34, No. 1 (Duke University Press, 2002), 268. See also Chandavarkar," Was Keynes Anti-Semitic?," 1623.

${ }^{102}$ Chandavarkar, "Was Keynes Anti-Semitic?," 1623.

${ }^{103}$ Hession, John Maynard Keynes, 15. 
enlightenment."104 The "balanced and mentally healthy scholar" as opposed to "the frustrated, inarticulate alienated and angry simpleton" is, in his view, a historical construct stemming from a class prejudice. Keynes, a great intellectual mind of his time, carried the burden of the prejudice of his era. Although Keynes' anti-Semitic undertones seem to be a mode of attracting the attention of listeners 54 through derogatory remarks, usually these undertones accompany the way to ridicule and embarrass those with a great deal of power and influence who either failed to impress Keynes or were potential rivals. Such a propensity to stereotype could be located in the milieu of Keynes' interpersonal battleground where he ruthlessly challenges the opponent with variability of nuances of either praise or defamation. We have to keep in mind that stereotyping was a common and pervasive contemporary feature. As a consequence of tumultuous fight for civil rights in the 20th century, modern society is more sensitive and cautious about stereotyping. Still, in regard to anti-Semitism, historians tend to treat even the slightest hints against Jews as anti-Semitic and fail to recognize their various differences and nuances. Skidelsky`s conclusion that Keynes' behavior carried a certain subversive quality which makes us think him more radical than he really was explains the essence of Keynes' charisma: "Keynes always tried to bring unformed thoughts to life, and not to kill them by pointing out mistakes." 105 Chandavarkar drew the "baffling asymmetry" between Keynes' better-known private antiSemitism and his almost unknown public philosemitism. Yet, it has been demonstrated above that even labeling Keynes an "anti-Semite in private" can spur disagreements between scholars if one fails to

\footnotetext{
${ }^{104}$ Barry Kosmin, "Judeophobia and the New European Extremism," 2005,2 http://www.yale.edu/isps/seminars/antisemitism/kosmin.pdf (17 November 2005)

${ }^{105}$ Hession, John Maynard Keynes, 160. 
question the meaning of anti-Semitism of Keynes milieu which naturally displayed the different range of signifieds ${ }^{106}$ than antiSemitism as understood by late twentieth or early twenty first century audiences. It can be concluded that Keynes uncritically reproduced the anti-Semitic clichés and even embellished them with additional layers of abstract, irrational or even mystical rhetorical twists. Yet, these utterances were usually a byproduct of specific situational tensions: professional rivalry and effort to claim respect and prestige among international elite. Keynes simply appropriated anti-Semitic clichés as a one facet of modus operandi in political circles. However, seeing himself as being "immoral," i.e. critical of generally accepted norms of his time, he naturally stood out as the defender of those that the society put down - hence his public philosemitism and sympathy for women's movement. Offering a new "lesson" based on the Keynes case seems to be pointless. Rather, getting rid of the layers of dust over the old one seems to be more relevant: it is "the lesson" about the necessity to question the meaning of those terms that in the course of decades successfully acquired the form of unquestioned self-sustaining "truth-s."

\footnotetext{
${ }^{106}$ Ferdinand de Saussure identified the linguistic sign as a two-sided identity - so called "dyad" which consists of the "signifier" (material aspect of the sign) and the "signified" ( mental concept). The signified represent an indelible part of the signifier. See more in Paul Cobley, Litza Jansz, Introducing Semiotics ( UK, Icon Books, Ltd, 2004), 8 -18.
} 